\title{
Public Finance of R\&D and the Obstacles to Innovation: The Case of Spain
}

\author{
Konstantinos Panagiotakopoulos, Jose Maria Fernandez-Crehuet, José Molero Zayas \\ ${ }^{1} \mathrm{PhD}$ student in Economics and Innovation Management, Complutense University of Madrid, Complutense Institute of \\ International Studies, Spain \\ ${ }^{2}$ Assistant Professor in Economics and Innovation at Universidad Politécnica de Madrid, Spain \\ 3Professor of Applied Economics, Complutense University of Madrid, Complutense Institute of International Studies, \\ Spain
}

Correspondence: Jose Maria Fernandez-Crehuet, Assistant Professor in Economics and Innovation at Universidad Politécnica de Madrid, Spain.

Received: July 20, 2018

doi:10.11114/ijsss.v6i12.3459
Accepted: November 6, $2018 \quad$ Available online: November 21, 2018

URL: https://doi.org/10.11114/ijsss.v6i12.3459

\begin{abstract}
This paper examines the importance of public financing in R\&D for Spanish companies and the correlation that exists between this kind of finance and the obstacles they encounter when innovating. For this, we have used a series of data obtained from the Technological Innovation Panel (PITEC) database for the year 2014. The number of observations used in this study is 7.071 and the models that are being developed are the Logit and Tobit models. From the analysis of these models, we conclude that the main obstacles that are relevant for the firms are related to the cost and knowledge factors, such as the lack of funding from outside sources or the excessive cost of innovation. However, market factors are not considered important for the companies, which always find a reason to innovate. Last but not least, we suggest which firms have the best chance of receiving public finance and make some reflections about the Spanish economy.
\end{abstract}

Keywords: public finance, obstacles, Spanish firms, subsidies, innovation, cost factors, knowledge factors, market factors

\section{Introduction}

The importance of public funding for innovation and growth in a country has been demonstrated in a great deal of research and work. Thus, according to the neoclassical theory (Varghese, 2013; Vargas-Hernandez, 2011; Medema, 2004; Mankiw, Kneebone, McKenzie \& Row, 2002; Bator, 1958), the public sector must intervene to solve market failures that impede the optimal development of innovation and that have to do with the "public nature" of it, although in fact the public agents may have other objectives as well, such as the promotion of the most successful national companies, or the technological development of companies that belong to traditional sectors (Clausen, 2007; Blanes \& Busom, 2004). These failures are associated with asymmetric information, policymakers' inability to decide which firms to favor and the existence of incomplete markets. Public funding fills the gap between private funding for Research and Development (R\&D) activities and the levels of socially optimal projects. Essentially, the innovations have positive external effects, generating social benefits, but companies usually only decide to launch innovation projects that are profitable for themselves or projects that at least cover their costs. For this reason, projects that create benefits for society are not launched and the investment in innovation in the market is less than the socially desirable level. The role of public funding is to reduce the price for private investors and, therefore, these innovations can be carried out (Almus \& Czarnitzki, 2002).

It is true that public funding should support R\&D projects that are socially desirable and that otherwise would not be realized. However, given the problems that have to do with the lack of information on R\&D projects, identifying projects that need public support is not easy. Typically, public policies that support private R\&D have consisted of tax breaks and, above all, public subsidies to partially finance private $R \& D$ projects. The conditions for eligibility and decision-making criteria are very broad and differ in time, as well as between countries or regions, and sectors of activity. Obviously, public intervention can have a negative effect on aggregate business R\&D if the companies that receive public funds reduce their own investment in R\&D, thus displacing private investment (crowding out effect) (David, Hall \& Toole, 2000). Nowadays, the empirical evidence is mixed, although approximately $60 \%$ of studies conclude that public subsidies are 
complementary and therefore increase private investment in R\&D.

However, a company always has a reason to apply for public support in $R \& D$, even if it could carry out the R\&D project using its own financial means. Market imperfections justify public intervention in business financing that allows companies to explore their technological potential and provides an incentive to take advantage of market opportunities. In many cases, public money has provided funding to successful technology companies in the early stages (Almus \& Czarnitzki, 2003).

Of course, public R\&D programs help companies in many ways. First of all, they build a stock of knowledge, increase the capacity to conduct future research projects, and form innovative and absorption capacities (Cohen \& Levinthal, 1989). The experience acquired through the implementation of R\&D makes it possible for companies to recognize, understand and apply $R \& D$ carried out by others. Therefore, since R\&D subsidies increase the participation of firms in $R \& D$ activities, those with aid would have a better chance of building their own absorption capacity and would therefore be more willing to carry out innovation activities. On the other hand, with the granting of public aid, companies develop their human capital of research workers and, above all, create important spillover effects. These spillovers help companies both develop projects that are already underway and start new projects. Finally, they increase the probability of these companies’ participating in cooperation projects (Fernández-Gual, \& Segarra-Blasco, 2013).

The public sector and the government have an extremely important role in the financing of R\&D activities. It should be noted that, according to EUROSTAT, in the last 10 years, the investment of governments in R\&D activities ranges from $30 \%$ to $35 \%$ in the European Union (for the 28 member states), from $27 \%$ to $31 \%$ in the United States, and between $16 \%$ and $18 \%$ in Japan. Therefore, a significant part of their R\&D budgets is used to subsidize the R\&D activities of private companies (COTEC, 2016).

In today's changing environment, where competition is increasing in almost all business areas, the need for change and innovation has probably never been greater. Although innovation is a risky and uncertain process that could make it seem reasonable not to innovate, an immobile approach is seldom an option. In fact, if companies are unwilling to continually renew their products and processes, their chances of survival are seriously threatened. Organizations need to be innovative across different products, services, technologies, processes or ideas, and be more effective in creating sustainable growth. The need to innovate is universal, regardless of the company's size, sector or level of technological sophistication (Cobbenhagen, 2000).

Unfortunately, most organizations have barriers to creativity, ideas and innovation, as our world is characterized by complexity, unpredictability and uncertainty. Since these barriers have a tendency to hinder the organization's creative possibilities, the identification and removal of barriers to creativity and innovation is crucial.

The reduction of productivity in Spain compared to other European Union countries can be attributed to the rapid growth of the Spanish market, which has not been accompanied by a simultaneous investment in the development of human resources and a greater investment in technology (Bank of Spain, 2006). The lagging innovation of Spanish companies compared to those of other industrialized countries could lead to Spanish companies being less competitive.

This article tries to analyze the importance of public investment in R\&D and to investigate the relationship that exists between this type of investment and some important factors, focusing as the title says on the role of the obstacles for Spain. Although a lot of studies have been done on the obstacles to innovation and public finance, this work uses only quantitative variables, thus emphasizing the characteristics of the firms and their behavior. Of course, this article takes into consideration the selection problem and endogeneity, which are problems that are analyzed below and that every work faces when it refers to public finance. The rest of the paper is divided into four parts. In the first part, the literature and empirical evidence are reviewed, indicating the most important criteria for public financing and its relation to obstacles. The second part analyzes the methodology that is used in this work, describing the database, the variables that are used and the models that are developed, while in the third part the results obtained through those models are analyzed. Finally, we offer our conclusions and some implications for future research.

\section{Literature Review}

\subsection{Innovation}

Because of the importance of innovation to sustain a competitive advantage and economic growth, this subject has gained the attention of eminent academics in management and economics. Schumpeter (1934) identified innovation as an engine for economic growth, arguing that the development of new or improved products will foster economic growth more effectively than the adjustment of prices for the same product. The importance of innovation for companies is underlined by Kleinknecht et al. (1997) who, similar to Schumpeter (1934), argue that innovative firms grow faster. The authors also point out that new processes and technologies are associated with a better allocation of resources, higher productivity and better quality of work. Firms performing innovation activities tend to offer products of higher quality and/or more 
favorable prices, while benefiting from greater growth potential (Minniti, Bygrave and Audio 2006).

According to Rogers (2003), innovation is "an idea, practice or object that is perceived as new by an individual or other unit of adoption." Specifically, this concept of "newness" does not necessarily mean the generation of new knowledge, but rather the modification or development of existing ideas. According to the Oslo Manual (OECD, 2005), an internationally recognized standard for measuring innovation, there are 4 types of innovation, which are outlined in the table below.

Table 1. The different types of innovation

\section{TYPE OF INNOVATION}

Product innovation

\section{DEFINITION}

A good or service that is new or significantly improved. This includes significant improvements in technical specifications, components and materials, software in the product, user-friendliness or other functional characteristics.

Process innovation

A new or significantly improved production or delivery method. This includes significant changes in techniques, equipment and/or software.

\section{Marketing innovation}

A new marketing method involving significant changes in product design or packaging, product placement, product promotion or pricing.

Organizational innovation

A new organisational method in business practices, workplace organisation or external relations.

Source: Oslo Manual (OECD), 2005.

Innovation does not usually take place in a static environment. Rather it is the result of a dynamic process in an organization involving the interaction of several internal and external factors. R\&D is an important (but not exclusive) part of the innovation process. It covers several systematic steps, such as requirements analysis, idea generation, idea evaluation, project planning, product development, testing and marketing (Verworn et al., 2006).

Scheme 1. The phases of a simplified innovation process
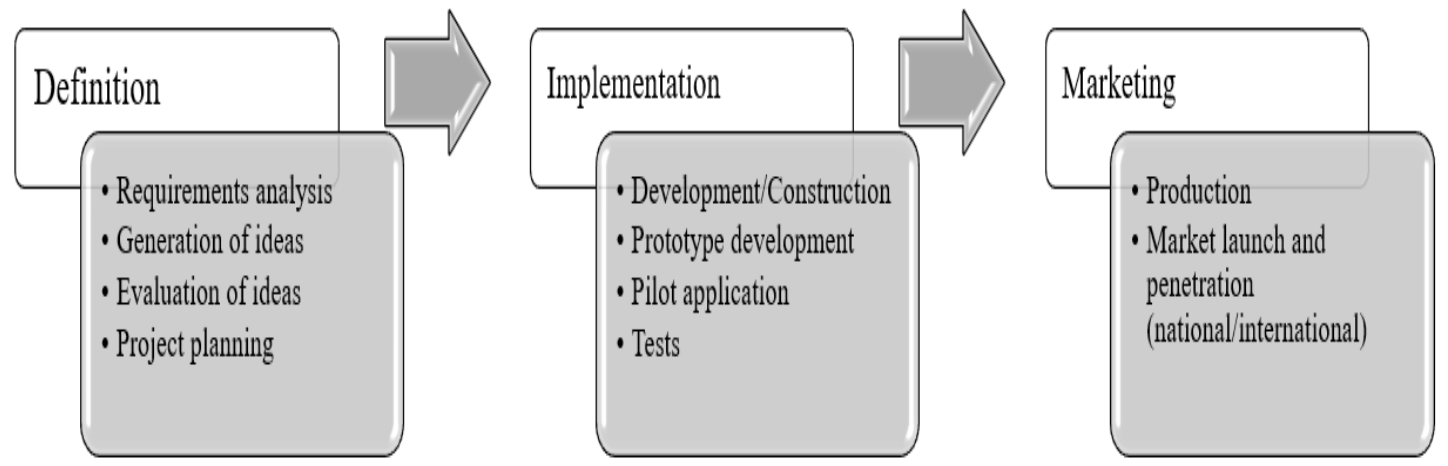

Source: Barriers to innovation in SMEs: Can the internationalization of $R \& D$ mitigate their effects? , 2005.

The ability to introduce innovative activities depends on the characteristics of the companies. Implementation is easier when there is less bureaucracy, owner experience, and a close relationship between owners and customers. Small business owners, who have limited external contacts and control all aspects of the business, are not aware that environmental changes and lack of adequate education/training can limit the company's innovative climate. In addition, strategic decisions made based on family rather than business criteria could encourage firms to reject the change needed to implement innovation (Hausman, 2005). Several studies show that the different barriers to innovation faced by firms were related to cost, institutional constraints, human resources, organizational culture, information flow and government policy. Small firms are particularly constrained by innovation barriers because of their limited resource base (Hewitt Dundas, 2006; Hadjimanolis, 1999).

\subsection{Public Finance and Obstacles}

There is a wide range of literature on the importance of funding and public intervention. One of the first to talk about public R\&D funding was Schumpeter. In his book “The Theory of Economic Development" of 1934, he highlighted three things: 1) that innovation depends on the investment of resources; 2) that innovation is incorporated into new companies that were founded to undertake new product combinations; 3) that innovation is driven by new entrepreneurs, 
entrepreneurs who were not previously in the market. In this book he states that SMEs are the vehicles of technological advances. In order to innovate, these companies need to use a variety of existing resources, but this raises the question how can new entrepreneurs control these resources, remove them from their ordinary uses, and combine them in a new way to innovate. The solution for Schumpeter is the funding system, and he claims that innovation should be funded through the creation of credit and the support of governments.

A few years later, in 1942, in his book "Capitalism, Socialism and Democracy" Schumpeter delves into funding policies. Contrary to what was stated in the previous publication, it states that innovation is created in large companies, which are those that use their profits to finance their R\&D activities. He argues that innovation is much larger in economies that have a few large companies that dominate the market, and states that risk is inevitable. It thus highlights the power of the market and governments' role in providing security against risks.

From a theoretical point of view, cost reduction for R\&D activities is the main channel through which public funding can impact business R\&D investment (Bloom et al., 2002). This is indisputable in the case of companies that decide to initiate R\&D activities. Considering the greater level of uncertainty of innovative projects and the public nature of knowledge, innovative firms generally face higher costs of external financing (their credit can even be rationed). Therefore, they mainly lean on their own resources to finance $R \& D$ projects. In this context, the decision to engage in $R \& D$ is sensitive to the availability of internal liquidity, whereas access to external sources of funding could convince companies to undertake R\&D projects that would not otherwise be initiated (Czarnitzki et al., 2011).

Taking this idea into account and looking at the establishment costs, González et al. (2005) model the relationship between the effectiveness of R\&D subsidies and the existence of barriers to R\&D. In the model developed in this work, the decision to invest or not in $R \& D$ arises from the comparison of an optimal non-zero effort with the necessary effort to achieve some profitability (threshold effort). Below this effort, $R \& D$ costs cannot be fully recovered, and companies will decide to refrain from innovative activities, but this decision can be modified if the expected subsidies reduce the cost of R\&D.

Specifically, subsidies to improve a country's R\&D expense have two options. First, the subsidies can function in an intensive way, seeking to promote the R\&D effort of companies already involved in regular R\&D (Huergo and Trenado, 2010; Aschhoff, 2008). On the other hand, the subsidies can act in an extensive way, seeking to increase the number of companies involved in R\&D (García-Quevedo, 2004; David et al., 2000). Only countries where a substantial proportion of companies are involved in $R \& D$ reach high intensities in $R \& D$. As a consequence, if the goal is to increase the intensity in $R \& D$, this can be achieved through the expansion of the number of innovative companies. That is why countries that operate only in the intensive way are likely to be unable to meet the European Commission's target of spending $3 \%$ of GDP on R\&D activities.

By developing a structural model and showing the interaction between those who apply for R\&D subsidies and those who finance them from both the public and private sectors, Takalo et al. (2013) analyze the effects of these subsidies and conclude that the higher costs of external finance constitute a very important reason to increase R\&D subsidies in the extensive way where companies can decide whether or not to invest in R\&D.

In fact, the repercussions of public $R \& D$ investment have been studied by several authors. There are those who find a positive relationship with private investment in $R \& D$ (Levy and Terleckyj, 1983), those who state that public and private investment are interdependent (Leyden and Link, 1991), and there are also authors who assert that public funding has a substitution effect on private investment (Carmichael, 1981). In addition, studies have found that these effects may be influenced by a firm's size, industry, technological intensity, economic environment and other factors.

Evidence on the impact of public aid on private $R \& D$ is mainly related to subsidy programs for $R \& D$ projects. Some of the most important studies that have been carried out to verify this include the following: Wallsten (2000) on US companies, Lach (2002) on Israeli companies, Busom (1999) and González et al. (2005) on Spanish firms, Czarnitzki and Licht (2006) on Innovative Enterprises in Germany and Duguet (2003) on the R\&D expenditure of companies in France. The variety of approaches presented in these documents lead their authors to conflicting conclusions on the relationship between public and private R\&D expenditure (Garcia-Quevedo, 2004; Zúñiga Vicente et al., 2014), although more recent indications suggest that public $R \& D$ subsidies succeed in motivating private $R \& D$ investment (Becker, 2015).

The table below shows the importance of public funding and the impact it has on different countries or regions. 
Table 2. Studies showing the magnitude of public funding in different regions

\begin{tabular}{cccl}
\hline YEAR & AUTHOR & COUNTRY/REGION & \multicolumn{1}{c}{ RESULTS } \\
\hline $\mathbf{2 0 0 2}$ & $\begin{array}{c}\text { Almus and } \\
\text { Czarnitzki }\end{array}$ & East Germany & $\begin{array}{l}\text { Companies that receive public R\&D funds achieve firmer R\&D intensities on } \\
\text { average in comparison with companies of similar characteristics that do not } \\
\text { receive public R\&D support. }\end{array}$ \\
\hline $\mathbf{2 0 0 4}$ & $\begin{array}{c}\text { Schibany } \text { et } \\
\text { al. }\end{array}$ & Austria & $\begin{array}{l}\text { Public intervention has positive effects on the additionalities of companies, as it } \\
\text { accelerates the course and time of projects, and companies have stated that their } \\
\text { results have improved drastically. }\end{array}$ \\
\hline $\mathbf{2 0 1 5}$ & Wong and He & Singapore & $\begin{array}{l}\text { Public subsidies are added to private R\&D funding and the regression methods } \\
\text { suggest that an additional dollar of public R\&D subsidies increases private R\&D } \\
\text { by } 40 \text { cents. }\end{array}$ \\
\hline $\mathbf{2 0 1 6}$ & Puffal et al. & Europe & $\begin{array}{l}\text { Companies that receive public support can be more efficient due to higher labor } \\
\text { productivity. }\end{array}$ \\
& Brazil & $\begin{array}{l}\text { The innovative capacity of companies is positively influenced by the use of } \\
\text { public funds to finance activities developed by the university-industry } \\
\text { interaction. }\end{array}$
\end{tabular}

Source: Own elaboration based on selected publications (first and second row).

Before we look at further studies that demonstrate the significant role that the public sector plays in encouraging companies to innovate, we must analyze the additionalities that have already been mentioned in the table above. Given the presence of imperfections in the market, the contribution of public intervention has been assessed according to the incidence of additionality effects associated with a variety of policy regimes (e.g. R\&D subsidies, public lending). There are three types of additionality: additionality of input, additionality of output and additionality of behavior. The positive impact of public assistance in terms of R\&D expenditure is considered as a form of additionality of input, while the positive effects in terms of new innovation outcomes are seen as a manifestation of additionality of output.

The additionality of input considers whether the finance provided by the government to a company complements the company's own expenses or substitutes them, i.e. if for each monetary unit provided by the public sector, the company spends at least one additional monetary unit in the development of R\&D activities.

Due to limitations in the additionality of input, researchers have attempted to measure the additionality of output, which attempts to measure the proportion of outputs that would not have taken place in the absence of public aid. In this way, the output additionality approach is concerned with quantifying the innovative output volume generated following the receipt of a subsidy.

Finally, based on a theoretical framework in which the innovation process is a cumulative, dynamic and interactive process, the term "additionality of behavior" is a framework used to explore the ways in which the agents to assimilate and exploit the results of research. In this latter additionality two changes can occur: changes to the established routines of a company and changes in the behavior of companies.

There are several studies that show the magnitude of the effect public funding has on each of these additionalities and the benefits that companies obtain. Evaluation studies confirm the presence of additionality of output in relation to direct and indirect R\&D policy regimes, i.e. R\&D subsidies and tax credit incentives, respectively. In relation to "marketable products", Hujer and Radić (2005) examine the impact of public R\&D subsidies in the case of Germany, finding evidence of additionality measured by the propensity of companies to introduce new products/services. In terms of indirect policies, Cappelen et al. (2012) confirm that R\&D tax credits increase the propensity of companies to patent and launch new products in the case of Norway. In relation to "commercial production", Hewitt-Dundas and Roper (2010) find that public funding in Ireland increases the sales of companies related to the introduction of new products. In the case of indirect public funding mechanisms, Bérubé and Mohnen (2009) show that highly supported firms in Canada, those receiving subsidies and R\&D tax incentives, are highly likely to introduce new products and be more successful in their marketing than unsupported companies.

Public intervention has positive effects on the additionalities of companies as it speeds up the course and time of projects, and companies have stated that their results have improved drastically. In addition, such funding covers the high costs of R\&D by reducing the risks and the obstacles that exist and is therefore very important for both small and medium-sized enterprises.

Becker (2015) in her work claims that the additionality effect is more important for small firms, which are more likely to experience external financial constraints. Indeed, these companies are more likely to start investing in R\&D if they receive a subsidy. In the same vein, Zuñiga-Vicente et al. (2014) show that public subsidies are very important for SMEs 
where liquidity constraints can be more severe.

In Europe, policy changes have intensified due to the increasing participation of the European Union (EU) and a gradual expansion of governments at the regional level (Cooke et al., 2000; Sanz Menéndez and Cruz Castro, 2005). As a result of this process, the nature of public support for private innovation has also changed, becoming more diversified and consistent with a broader policy framework encompassing regional, national and international interests.

In his paper, Ribas (2009) states that participation in regional programs is more likely to be observed among nationally owned enterprises facing major obstacles to innovation. Participants in national and pre-competitive international programs are more likely to come into contact with other national firms with experience in patents as well as companies operating in high-knowledge industries. In addition, receiving public support from national sources increases the likelihood that companies will cooperate to innovate with both national and international partners.

The evaluation of public R\&D funding is an important issue in the industrial economic literature. Hussinger (2008) focuses on public subsidies for R\&D projects in the German manufacturing sector. Using econometric models, it shows that the most important variables are the size of the company, the innovative activities of the company in the past and a regional model. The size and location of the company has a very large impact on R\&D expenditure and the receipt of public R\&D funding. Finally, it has been concluded that public funding increases the R\&D spending of companies.

An important issue regarding public funding is how to choose which companies will receive public support, which is known as the selection problem. There are some criteria that public agencies consider important when selecting which companies should receive financing, such as: i) companies or projects with a higher probability of success (selection of picking the winner); ii) particular sectors that generate more spillovers; or iii) certain groups of companies facing greater financial constraints (generally SMEs). Indeed, one must consider that the same characteristics of the company that define its behavior in $R \& D$ also affect its participation in the aid system.

Another outstanding issue is the endogeneity of such funding. Companies that invest more in R\&D activities receive the highest public funds, which means that the estimated impact of public funding has included the effect of other variables that influence R\&D expenditure. In addition, R\&D spillovers that are generated can cause changes in the behavior of companies that do not participate in the public aid system. This occurs indirectly as a result of the behavior of the companies that do participate. Becker (2015) points out that the availability of new econometric techniques that monitor selection bias is probably one reason to move away from previous findings that public subsidies often exclude private $R \& D$ and suggests that subsidies actually stimulate private $R \& D$, as discussed above.

Innovation is a key driver of economic development. As a result, governments have invested considerable financial resources over the years to promote R\&D activities by enterprises and to foster the development of technological innovation. The European Commission is working on a strategic approach to innovation and is developing many policy instruments to help companies to better develop R\&D activities (e.g. financial support, such as the Research Framework Program). These public policies aim to reduce perceived obstacles to innovation, i.e. the factors that discourage companies from investing in $\mathrm{R} \& \mathrm{D}$, which hinder the achievement of tangible results, or which hinder the development of technological innovation.

Taking into account the objectives of industrial policies and the relevance of a systemic view of innovation activities, Galia et al. (2012) try to work out what the barriers to innovation are and whether they vary from country to country. Compared with existing literature, the novelty of its work includes a detailed international comparison of two countries (France and Italy), and an in-depth analysis of the factors that influence the barriers to innovation. It has been demonstrated that the structural characteristics of the company influence the perception of cost, knowledge and market barriers. In general, large companies face fewer obstacles than other companies, with the exception of barriers related to lack of information on technology and the market. When a company becomes larger and when it has been operating for a longer period of time, the collateral it can contribute increases, as well as its track record. As a consequence, the financial barriers decrease for older companies. Belonging to a group reduces the perception of internal financial constraints, the lack of qualified staff and the difficulty of finding partners in R\&D. Companies in the manufacturing industry are more aware of the high costs of innovation and the presence of established companies in the market; high-tech industry firms are less aware of the lack of market information and obstacles due to the uncertainty of demand. The use of intellectual property rights reduces the perception of high innovation costs. The use of external sources of information improves the perception of financial constraints, the lack of market information and the difficulty finding R\&D partners. External R\&D activities, compared with internal ones, seem to reinforce barriers to innovation. On the other hand, the results suggest that companies cooperating in $R \& D$ are more likely to recognize and perceive the difficulty of finding valid R\&D partners.

A few years later, Galia et al. (2015) group firms into three categories according to their attitude towards innovation: (i) innovators; (ii) active innovative; (iii) active non-innovative. The public sector supports companies by stimulating the performance of innovation and favoring innovative efforts. Descriptive statistics emphasize that the scope of perceived 
barriers to innovation is similar across innovation profiles, apart from the bottleneck effect of innovation costs that is most evident for active innovative firms. However, the econometric estimation of the determinants suggests that the drivers of the perception of obstacles vary across innovation profiles. They have found that public policies aimed at supporting innovation development may differ from the ones aimed at encourage innovation activities.

Companies that do not pursue pioneering strategies often face barriers to innovation. Different obstacles to innovation are faced by different groups of SMEs, with funding problems that mainly affect small and young SMEs, and companies that follow growth strategies. The bureaucratic obstacles, in turn, affect mainly companies that belong to the construction sector. For an additional group of SMEs, the most widespread barriers to innovation are organization and skill-related problems, coupled with financial difficulties and high market risk. This is what Zimmermann (2016) says in his paper, where he analyzes the obstacles to innovation and argues that support for innovation for SMEs must be broadly based and include both financial and non-financial support. Specifically, it shows that financial obstacles are the most important when it comes to innovating.

Tiwari and Buse (2007) have established that global innovation opens up new areas for companies, especially SMEs, to strengthen their innovation capacities and increase their competitiveness in a global world. In this respect, the internationalization of $R \& D$ and its public funding seem to be useful tools to mitigate the effects of the obstacles to innovation that SMEs often face in industrialized economies.

In the case of Spain, many studies have examined the impact of public R\&D funding. González and Pazó (2008) use the data set of Survey on Corporate Strategies (ESEE) for the period 1990-1999. The main results include the absence of a partial or total crowding out effect, strengthening the international evidence obtained with the same methodology. On average, the effort of the subsidized companies is 0,35 percentage points higher; this is quite significant, since the average effort is $2,1 \%$ in the absence of a subsidy. In addition, public funding is more effective for small businesses operating in low-tech sectors.

Guijarro et al. (2009) in their article present the results of a study that examined the obstacles to business innovation in a sample of 294 managers of SMEs in Spain. The study examined the relationship between: (i) product, process and management innovation; and (ii) 15 barriers to innovation, which may limit a company's ability to remain competitive and profitable. The results of the study show that the barriers have a differential impact on the various types of innovation. Product, process and management innovation are affected differently by different barriers. The most significant barriers are associated with costs, while the less significant ones are associated with manager/employee resilience. In addition, the results show that the costs associated with innovation have a proportionately larger effect on small firms than large firms. Its conclusions can be used in the development of public policies aimed at supporting and promoting innovation among SMEs in Spain. Government policies that encourage and support innovation among all businesses, especially small ones, can help countries remain competitive in a global marketplace.

It is clear that the bibliography related to the public financing of $R \& D$ and the obstacles to innovation is very extensive. Several studies have demonstrated the importance of such funding, and many have focused their research on the barriers to innovation. The literature on innovation clarifies that the participation of the Government and the Public Administrations is an important element to promote the technological innovation of a country, as it is associated with the growth and development of a nation, and helping to reduce the barriers that the companies encounter when innovative activities are carried out.

Spain is a very peculiar market. In terms of R\&D funding, it is observed that public funding has shown a high degree of volatility, which is an anomaly that is not observed in the leading countries in innovation. Following the continuous growth during the first decade of the 21st century, in recent years there has been a succession of budgetary adjustments that have affected R\&D investment.

In particular, in 2014 , the private sector financed $47,1 \%$ of $R \& D$, followed by the public sector $(45,5 \%)$ and the foreign sector $(7,4 \%)$. Although this distribution is shared by other countries (such as Portugal and Italy), there is a difference between these percentages and what is observed in most developed countries. In this sense, private participation is higher in the EU-28 (54\%), and clearly higher in the OECD or the United States (60\%), reaching around 75\% in countries such as Japan or South Korea (which also lead global investment rankings). Traditionally, the fiscal framework of R\&D in Spain has been considered as theoretically generous, but with a limited practical application by SMEs. This was pointed out by the European Commission's European Research Area Committee (ERAC) in its 2014 report on the state of the Spanish innovation system. Specifically, it pointed out that, although public funding was slightly higher than private funding, after the crisis there was a large decline in both types of funding, and in particular the decline in public funding was more intense than that of private finance (in 2013, public sector funding was 5,7\% lower while that of the private sector dropped by $1,5 \%)$.

Studying the obstacles that Spanish companies face when they innovate is important for the design of public policies 
aimed at increasing the number of innovative companies, the volume and the success rate of investment related to R\&D and the innovation. Knowing the challenges and the main obstacles that innovative companies face to intensify their efforts, as well as the obstacles encountered by non-innovative companies, is an essential step when designing public actions.

Although the majority of the studies demonstrate the relevance of public intervention through quantitative models, this paper determines the importance of public finance and the relation that it has with the obstacles to innovation using a qualitative method. Specifically, the use of qualitative, binary variables from a quantitative dataset helps us understand which obstacles are considered more important for the Spanish firms and what characteristics and behavior of firms increase the chance of receiving public finance. This will be demonstrated using two models, the Logit and Tobit models. Apart from that, the database that is used is broader and more recent, since this model contains variables covering the period between the years 2008 and 2014.

\section{Methodology}

\subsection{Database}

The database used for this work is the database of the Technological Innovation Panel (PITEC-Panel de Innovación Tecnológica). This panel is a statistical instrument for monitoring the technological innovation activities of Spanish companies. The database is being built by the National Institute of Statistics (INE), with the advice of a group of researchers from the university, under the patronage of FECYT. Initiated in 2004, the final objective of this project is to contribute to the improvement of the statistical information available on the technological activities of companies and the conditions for carrying out scientific research on them.

This work takes into consideration for the analysis the year 2014, although data from 2008 is used to generate some variables that affect the granting of public funds. In 2008 the PITEC database changed a lot, and this happened because in that year the codes of the sectors to which the companies belong changed. For this reason, although PITEC provides data from 2003 to 2014, the generation of these variables takes 2008 as its starting year. Variables from this database were used to develop the models in the following section.

\subsection{The Variables}

The variables used in this work are based on the available literature and they depend on their availability in the database. As already mentioned, PITEC is used as the database.

The existing literature demonstrates that there are specific characteristics for the participation or not of the companies in the public financing of R\&D. Some of the most important works are by González et al. (2005), Heijs (2005), Czarnitzki and Licht (2006), Clausen (2007), Huergo y Trenado (2010), Takalo et al. (2013), Huergo et al. (2016).

First of all, the obstacles that companies find when innovating are defined. According to PITEC, there are 11 obstacles faced by companies and these are divided into four categories, as indicated in the table below.

Table 3. Definition of the obstacles that companies face when innovating

\begin{tabular}{|c|c|}
\hline Cost factors & $\begin{array}{l}\text { Lack of funds in the company } \\
\text { Lack of funding from outside sources } \\
\text { Cost of innovation too high }\end{array}$ \\
\hline Knowledge factors & $\begin{array}{l}\text { Lack of qualified personnel } \\
\text { Lack of information on technology } \\
\text { Lack of market information } \\
\text { Difficulties finding partners to innovate }\end{array}$ \\
\hline Market factors & $\begin{array}{l}\text { Market dominated by established companies } \\
\text { Uncertainty regarding the demand for goods }\end{array}$ \\
\hline Reasons not to innovate & $\begin{array}{l}\text { It is not necessary due to previous innovation } \\
\text { It is not necessary because there is no demand for innovation }\end{array}$ \\
\hline
\end{tabular}

Source: Own elaboration through the PITEC database

The obstacles mentioned above oscillate on a scale that goes from 1 to 4 according to the importance of each barrier for each company. In this model, the barriers that are assigned a value of 1 are considered very important for companies, while those with a value of 4 are considered irrelevant or not applicable. For this work, and the Logit and Tobit models that follow, the obstacles that receive the number 1 are those of the values 1 or 2 (i.e. they are quite important for the firms) and the obstacles that do not affect the companies receive a value of 0 , i.e. scale 3 or 4 .

Variables that reflect the financial position of a company are considered important, particularly when there are financial restrictions. As mentioned in previous sections, $R \& D$ activities involve high commercial and technical risks. There is high uncertainty as to the achievement of technological objectives, and even if projects succeed, the results may not be 
profitable due to the lack of demand and/or the reaction of competitors in terms of new inventions. As a result, financially healthy companies are more able to undertake greater R\&D investment. In this sense, the financial support received by the companies awarded public funding can serve as a big incentive for companies with financial constraints, increasing their probability of carrying out technological activities (Huergo et al., 2016).

Indeed, cost factors explain a company's difficulties in financing its innovation projects and play a very important role in public intervention. Overall, this factor has been shown to be most important for SMEs and start-ups (Hall, 2002).

Knowledge factors refer to the access to information about technology and skilled labor. Specifically, it refers to problems in obtaining adequate equipment and knowledge to carry out the project. It has been demonstrated that companies with employees qualified to undertake $R \& D$ activities are more likely to innovate, since such employees have a capacity for change and highly creative problem-solving abilities (Leiponen, 2005). On the contrary, the lack of labor reduces the possibilities of innovation and is one of the main factors that prompts large Spanish companies to abandon innovation activities (García-Vega and Lopez, 2010).

On the other hand, the market factors explain the structure of the market and refer to the difficulty that companies face in predicting the reaction of consumers to the supply of new products. For this reason, this factor reflects the problems of exploiting the innovation that occurs when the market is dominated by established companies or by the uncertainty with respect to the demand of goods and services.

In addition, more control variables are introduced. One variable is the R\&D expenses of a company. The more a company spends on such activities, the more innovative it is, thus making it the more likely that it will face obstacles to innovation and thus call for public intervention to overcome them.

The other variable used is a dummy variable. The size of the company is a variable that is widely used in the literature on public R\&D funding, although its impact on participation is not very clear. Large firms typically have more resources to undertake R\&D projects and seek public aid, but SMEs are often more affected by market failures related to innovation, so their public aid benefits could be greater. In this work, the size of the company is 0 if the company has less than 200 employees, and 1 if it has more than 200 employees.

Another variable that is used is the ability of the company to patent, which is a variable that shows the competitive position of the company in the market. A company that patents more means it is more competitive than other companies in the market and has more incentives to innovate and invest in R\&D activities. For this reason, it is more likely to participate in public funding competitions to overcome the barriers it finds in its path and to continue patenting and innovating. Companies that have patented at least once are given the value 1 and companies that have never patented are given the value 0 .

A company's expenditure on the acquisition of external knowledge is another variable that has been verified in the work. It has been shown that this expenditure contributes positively to the effects of innovation (Leiponen and Helfat, 2010), as it is a very important input for the same and examples of this include technology expertise, the development of new goods and services or processes that are generated externally to the company and transferred to it to facilitate its R\&D activities.

On the other hand, the biotechnology sector today is a sector of growing interest, both in academic circles and in economic activity. A broad definition of biotechnology would be a set of technological innovations based on the use of microorganisms and microbiological processes for the procurement of goods and services and for the development of scientific research activities. Biotechnology has a great deal of potential in the field of scientific research and development, as it provides tools that considerably reduce $\mathrm{R} \& \mathrm{D}$ deadlines, especially in the biological field. Thus, its possible incorporation in the econometric model has been considered to be of special interest. However, its effects on public funding are not relevant. This variable is a dummy variable, receiving the value of 1 if the company carries out biotechnological activities and 0 if it does not.

The next variable has to do with the accumulation of public funding. A table in Annex A shows the sectors that have received the most public funding and those that have received the least from 2008 to 2014. Using this table, a taxonomy has been generated by classifying the companies as having high, medium and low levels of accumulation of public financing. The value 1 is given if the company belongs to the high accumulation group and 0 otherwise. In fact, $75 \%$ of public funding belongs to 8 sectors out of the 44 that exist and that means that public funding accumulates in specific sectors (the 8 sectors that are the most advanced technologically).

Finally, the bipublifun_old is a binary variable that has been generated to show whether the company has received public funding from 2008 to 2013, which may affect its participation in public funding competitions in the future. Investing in R\&D activities in one period can make a company more likely to invest in the next one too, which increases the possibility of seeking public aid. A firm's experience with subsidies increases its chances of being selected for a grant again and this is due to word of mouth rather than the company's efforts to innovate or the social benefits of the project (Antonelli et al., 
2013). Since it is a binary variable, it receives the value 1 if the company has received public funding in previous years and 0 if it has not. This variable has been generated by making a list of all the companies that have received financing between the years 2008 and 2013 (Annex 2) and we also considered each year individually and found the sum total.

Table 4. Definition of the variables

\begin{tabular}{lc}
\hline Variables & Definition \\
\hline costfac1 & Lack of funds within the company or group \\
costfac2 & Lack of external financing to the company \\
kntfac3 & High innovation costs \\
knowfac2 & Lack of qualified personnel \\
knowfac3 & Lack of information on technology \\
knowfac4 & Lack of market information \\
markfac1 & Difficulty in finding partners for cooperation in innovation \\
markfac2 & Market dominated by established companies \\
noinnfac1 & Uncertain demand for innovative goods and services \\
noinnfac2 & Not needed by previous innovations \\
inexrd & Not needed due to lack of demand for innovations \\
size200 & Cost of internal R \& D expenditure \\
pat & Number of employees equal to or greater than 200 \\
techno & Patent Application \\
bio & Expenditure on acquisition of external knowledge \\
highaccum & Biotechnology \\
bipublifun_old & High accumulation of public funding \\
\hline
\end{tabular}

Source: Own elaboration through the PITEC database.

\subsection{Methods}

The econometric models used in this paper in section 4 are the Logit and the Tobit models. Logistic regression allows us to obtain estimates of the probability of an event and to identify the factors and the most important variables that determine these probabilities, as well as the influence or relative weight that they have on these probabilities. The Logit model is similar to traditional regression except that logistic regression is used as an estimation function rather than linear regression. In fact, there are different types of Logit, but the Logit model of dichotomous response has been used, which is used when there are two mutually exclusive alternatives.

The endogenous variable of this work is the receipt or not of public financing, which is a binary variable since it has the value 1 if the company receives public funding to carry out $R \& D$ activities, and 0 if it does not receive public aid. The other exogenous variables that have been analyzed are the variables that are considered to have more explanatory power with respect to the endogenous variable.

The results of the model give rise to a series of coefficients, each of which individually represent the probability that the endogenous variable is assigned the value of 1 , for each unit increase in each coefficient, respectively. In sum, this should reflect a company's chances of obtaining public funding by including the most qualitatively and quantitatively important factors.

On the other hand, the Tobit model (normal censored or truncated) is used to analyze the influence of a series of factors that are used as independent variables on a binary variable which is public financing.

The Tobit regression can be proposed for a dependent variable censored both at the lower end and at the upper end of its cumulative normal distribution or both. This model is a mixture of the regression model and the Probit model. It is partially Probit because the grant financing is binary, and is partially a linear regression model because the relationships considered are linear but bearing in mind that we are dealing with probabilities of obtaining 1 in the endogenous variable the likelihood function is being used.

\section{Results}

The Logit model is used mainly to find the correlation between the independent variables and public R\&D funding for the year 2014.

The number of model observations is 7.071 with 7.062 degrees of freedom (number of observations-number of variables-1). On the other hand, chi2 is a statistical test for the meaning of the model in its entirety under the null hypothesis; the null hypothesis is that all regression coefficients are simultaneously equal to zero. That is, it examines the extent to which the relationship between the dependent variable and the set of independent variables is significant. With a confidence level of 
$95 \%$, the model is significant if the probability that appears is below a significant level a that is usually set at 0,05 . The null result of the p-value of the test would lead one to conclude that at least one of the regression coefficients in the model is not equal to zero and accept the model as feasible and reliable. As such it can be said that the relationship between the coefficients of the model and the probability of receiving public funding is statistically significant.

Table 5. Logit Regression and analysis of the results

\begin{tabular}{|c|c|c|c|}
\hline & Coeficients ( $\mathrm{z}$ test) & S.E. & $\mathbf{P}>|\mathbf{z}|$ \\
\hline costfac2 & $\begin{array}{l}0,675^{* * *} \\
(6,33)\end{array}$ & 0,107 & 0,000 \\
\hline costfac3 & $\begin{array}{l}-0,229^{* *} \\
(-2,24)\end{array}$ & 0,102 & 0,025 \\
\hline knowfac3 & $\begin{array}{l}0,216^{* *} \\
(2,39)\end{array}$ & 0,090 & 0,017 \\
\hline knowfac4 & $\begin{array}{l}0,194^{* *} \\
(2,14)\end{array}$ & 0,090 & 0,032 \\
\hline size200 & $\begin{array}{l}0,432^{* * * *} \\
(4,68)\end{array}$ & 0,083 & 0,000 \\
\hline pat & $\begin{array}{l}0,969^{* * * *} \\
(9,10)\end{array}$ & 0,106 & 0,000 \\
\hline highaccum & $\begin{array}{l}0,432^{* * * *} \\
(4,68)\end{array}$ & 0,092 & 0,000 \\
\hline bipublifun_old & $\begin{array}{l}3,207^{* * * *} \\
(25,49)\end{array}$ & 0,126 & 0,000 \\
\hline cons & $\begin{array}{l}-4,750^{* * *} \\
(-33,11)\end{array}$ & 0,143 & 0,000 \\
\hline Observations & 7.071 & & \\
\hline LR chi2(8) & $1.900,61$ & & \\
\hline Prob > chi2 & 0,0000 & & \\
\hline Log likelihood & $-1.974,3474$ & & \\
\hline
\end{tabular}

Source: Own elaboration through the PITEC database. 1) costfac2, costfac3, knowfac3, knowfac4: dichotomous variables that receive the value 0 if the obstacles are not considered important by the company and 1 if they are considered important. 2) pat: dichotomous variable that receives the value 1 if the company has patented at least once and 0 if it has never patented. 3) tam200: dichotomous variable that receives the value 0 if the company has less than 200 employees and 1 if it has more than 200 employees. 4) bifonpubli_antes: dichotomous variable that receives the value 1 if the company has received public funding at least once from 2008 to 2013 and 0 if not. 5) S.E.: Estimated standard error. Coefficients significant at: $1 \% * * *, 5 \% * *$, and $10 \% *$.

The $\mathrm{z}$-value is the coefficient of each regression variable divided by its standard error. These $\mathrm{z}$-values are calculated under the hypothesis test that the coefficient of the variable is 0 . This value indicates to what extent each coefficient has a significant effect on the equation. If the z-value is large in magnitude (positive or negative), the null hypothesis is rejected, indicating that the corresponding coefficient is not 0 and the corresponding variable is important for the model.

The $\mathrm{P}>|\mathrm{z}|$ is the probability that the test statistic $\mathrm{z}$ is observed under the null hypothesis that the coefficient of a particular variable is zero, since all other variables are stable (ceteris paribus) in the model. For a given level, $\mathrm{P}>|\mathrm{z}|$ determines whether the null hypothesis can or not be rejected. If $\mathrm{P}>|\mathrm{z}|$ is smaller than $\mathrm{a}$, the null hypothesis can be rejected and the parameter estimate is considered statistically significant at that level a.

Indeed, all variables in Table 5 are considered statistically significant, since $\mathrm{P}\rangle|\mathrm{z}|<\mathrm{a}$. From the model the variables costfac1, knowfac1, knowfac2, markfac1, markfac2, noinnfac1, noinnfac2, inexrd, techno and bio were excluded because they were not statistically significant, since $\mathrm{P}>|\mathrm{z}|>\mathrm{a}$.

The signs of the coefficients in Table 5 have not always resulted in the same expected meaning in the theoretical model proposed. The coefficient of the variable costfac 2 is 0,6750473 . This means that, if the company encounters this obstacle when it comes to innovating, the endogenous variable estimated by Logit increases by an average of 0,68 units whereas if it finds the obstacle costfac 3 , the dependent variable decreases by an average of 0,23 units, suggesting a negative relationship between public funding and this obstacle. The constant term is $-4,750$ and it is assigned the 0 value for the qualitative explanatory variables of model plus other factors that can be relevant and that are not considered. 
Another explanation that can be given for the obstacle costfac3 would be in terms of the opportunities, which can be calculated through the antilogarithm of the coefficient which in this case is $\mathrm{e}^{-0,229}=0,796$. Values greater than 1 indicate greater opportunities for the event to occur while values below 1 indicate fewer opportunities. In this case, the opportunities for a company to receive public funding in face of this obstacle are lower than otherwise. To find the importance of this opportunity, it is necessary to divide the unit by this value $1 / 0,796=1,257$. That means that if the company faces the costfac 3 obstacle, its opportunity to receive public funding is an average of 1,26 times lower than a company that does not face it.

From the table 5 it becomes clear that if the company has received public funding from previous years, the possibility of obtaining new financing is extremely high. Specifically, the dependent variable increases by an average of 3,21 units for each unit increase of the aforementioned variable. This variable can be interpreted in a similar way as costfac 3 to find the probability of this event. For the estimated coefficient and applying the antilogarithm, it is observed that the opportunities that the company receives public financing if it has received it in one of the last few years are $\mathrm{e}^{3,207}=24,714$, keeping the other factors constant. In this case it is not necessary to divide the coefficient because the value of the calculated antilogarithm directly gives the opportunities, since that coefficient is positive.

This opportunity specifically in the first case is called odds ratio while in the second it is called odds. Odds are interpreted as ratios, that is, the number of times something may happen that cannot happen while the odds ratios as the proportion of the probabilities of success for one group divided by the probabilities of success for the other group.

Table 6. The odds ratio for the Logit model

\begin{tabular}{ll}
\hline costfac2 & Coeficients \\
costfac3 & $1,964 * * *$ \\
knowfac3 & $0,796 * *$ \\
knowfac4 & $1,241 * *$ \\
size200 & $1,214 * *$ \\
pat & $1,540 * * *$ \\
highaccum & $2,635 * * *$ \\
bipublifun_old & $1.676 * * *$ \\
cons & $24,714 * * *$ \\
\hline
\end{tabular}

The table 6 shows the odds and odds ratio for all variables (although odds are ratios, they should not be confused with odds ratios). When the odd ratio is 1 indicates absence of association between the variables. As previously discussed, values less than 1 indicate a negative association between variables and values greater than 1 indicate a positive association between the variables. The higher the odds ratio of 1 , the stronger the relationship.

Source: Own elaboration through the PITEC database. S.E: Estimated standard error. Coefficients significant at: $1 \% * * *$, $5 \% * *$, and $10 \% *$.

Table 7. Marginal effects of the variables

$y=\operatorname{Pr}($ bipublifun) $($ predict $)=0,054$

\begin{tabular}{|c|c|c|c|}
\hline & dy/dx (z test) & S.E. & $\mathbf{P}>|\mathbf{z}|$ \\
\hline $\operatorname{costfac} 2 *$ & $\begin{array}{l}0,038 \\
(6,12)\end{array}$ & 0,006 & 0,000 \\
\hline $\operatorname{costfac} 3 *$ & $\begin{array}{l}-0,012 \\
(-2,17)\end{array}$ & 0,006 & 0,030 \\
\hline knowfac3* & $\begin{array}{l}0,011 \\
(2,28)\end{array}$ & 0,005 & 0,022 \\
\hline knowfac4* & $\begin{array}{l}0,010 \\
(2,06)\end{array}$ & 0,005 & 0,039 \\
\hline $\operatorname{size} 200 *$ & $\begin{array}{l}0,024 \\
(4,22)\end{array}$ & 0,006 & 0,000 \\
\hline pat* & $\begin{array}{l}0,072 \\
(6,25)\end{array}$ & 0,011 & 0,000 \\
\hline highaccum* & $\begin{array}{l}0,030 \\
(5,29)\end{array}$ & 0,006 & 0,000 \\
\hline bipublifun_old* & $\begin{array}{l}0,286 \\
(26,86)\end{array}$ & 0,011 & 0,000 \\
\hline
\end{tabular}

(*) dy/dx is for discrete change of dummy variable from 0 to 1 .

Source: Own elaboration through the PITEC database

The probability of a company receiving public funding on average according to the Table 7 is approximately $5,40 \%$. If the company faces the costfac 2 obstacle on its way to innovation, the probability of receiving public funding increases on 
average by approximately 3,4 percentage points whereas if it finds the obstacle costfac 3 , its probability of receiving subsidies decreases 1,2 percentage points.

Table 8. Ratio of success of the variables highaccum y bipublifun_old

\begin{tabular}{|c|c|c|c|}
\hline & \multicolumn{2}{|c|}{ highaccum } & \\
\hline bipublifun & 0 & 1 & Total \\
\hline 0 & 4.783 & 1.264 & 6.047 \\
\hline 1 & 565 & 459 & 1.024 \\
\hline Total & 5.348 & 1.723 & 7.071 \\
\hline
\end{tabular}

\begin{tabular}{|c|c|c|c|}
\hline & \multicolumn{2}{|c|}{ bipublifun_old } & \multirow[b]{2}{*}{ Total } \\
\hline bipublifun & 0 & 1 & \\
\hline 0 & 4.399 & 1.648 & 6.047 \\
\hline 1 & 76 & 948 & 1.024 \\
\hline Total & 4.475 & 2.596 & 7.071 \\
\hline
\end{tabular}

Source: Own elaboration through the PITEC database.

Table 8 shows the proportion of success for the variables highacum and bipublifun_old. In cases 00 and 11 in both tables the value of the dependent variable will have been predicted correctly and therefore the ratio of success will be given by the quotient successful cases/possible cases. This table contrasts the available observations on the number of companies receiving or not public financing with the predictions made by the model.

From the first table it can be seen that of the 6.047 companies that do not receive public financing, the model ranks well at $4.783(79,10 \%)$, while of the 1.024 that receive public funding, it correctly classified $459(44,82 \%)$. Finally, the adjusted model adequately classifies $74,83 \%$ of the data (5.242 out of the 7.071 companies). The same can happen for the second variable bipublifun_old. In this variable, of the 6.047 companies that do not receive subsidies, the model ranks well at $4.399(62,21 \%)$, while of the 1.024 that receive public aid correctly classified $948(92,58 \%)$. That is, the model correctly classified $75,62 \%$ (5.347 of the 7.071 companies).

Below the Tobit model is used to estimate the linear relationship between the independent variables when the dependent variable is censored. The model assumes that there is a latent variable. This variable depends linearly on the other variables through the coefficients that determine the relationship between the latent variable and the independent variables. In addition, there is an error term with a normal distribution to capture the random influences in this relation and what could not be collected in value with the explanatory variables considered. For Tobit model analysis, a lower limit of the observable variable has to be specified. In this case the lower limit is 0 , since the dependent variable is binary and equals 0 if the company does not receive public funding.

Table 9. Tobit regression and analysis of results

\begin{tabular}{|c|c|c|c|}
\hline & Coeficients (z test) & S.E. & $\mathbf{P}>|\mathbf{z}|$ \\
\hline $\operatorname{costfac} 2$ & $\begin{array}{l}0,413^{* * *} \\
(6,47)\end{array}$ & 0,064 & 0,000 \\
\hline costfac 3 & $\begin{array}{l}-0,138^{* *} \\
(-2,26)\end{array}$ & 0,061 & 0,024 \\
\hline knowfac3 & $\begin{array}{l}0,121^{* * *} \\
(2,20)\end{array}$ & 0,055 & 0,028 \\
\hline knowfac4 & $\begin{array}{l}0,128^{* * *} \\
(2,35)\end{array}$ & 0,055 & 0,019 \\
\hline size200 & $\begin{array}{l}0,199^{* * *} \\
(3,62)\end{array}$ & 0,055 & 0,000 \\
\hline pat & $\begin{array}{l}0,583^{* * *} \\
(9,00)\end{array}$ & 0,065 & 0,000 \\
\hline highaccum & $\begin{array}{l}0,398^{* * *} \\
(5,85)\end{array}$ & 0,051 & 0,000 \\
\hline bipublifun_old & $\begin{array}{l}1,890^{* * *} \\
(25,84)\end{array}$ & 0,073 & 0,000 \\
\hline cons & $-2,789^{* * * *}$ & 0,103 & 0,000 \\
\hline
\end{tabular}


$(-27,04)$

\begin{tabular}{cc}
\hline & \\
\hline Observations & 7.071 \\
LR chi2(8) & $1.985,04$ \\
Prob > chi2 & 0,0000 \\
Log likelihood & $-2.825,1687$ \\
\hline
\end{tabular}

Source: Own elaboration through the PITEC database. Coefficients significant at: 1\%***, 5\%**, and 10\%*. Observations summary: 6.047 left-censored observations at bipublifun $<=0.1 .024$ uncensored observations.

The coefficients in the Tobit model basically estimate the marginal effects of the explanatory variables on the latent variable. Obviously, the observation of the signs of the coefficients does not contradict what was expected in the theoretical approach of the model. In fact, the marginal effect of the costfac 2 obstacle is equal to 0,413 , which means that it is an obstacle with a relatively important weight for the companies, since for each unit of marginal increase of this obstacle the company's chance of receiving public funding increases by 41,32 percentage points. On the other hand, the obstacle to costfac3 shows a negative marginal effect, which is translated into a relatively less important burden for enterprises and for each unit of marginal increase of this obstacle the company's chance of receiving public funding decreases by 13,77 percentage points. Through Tobit, it is verified that the independent variable bipublifun_old is very significant for the firms, since the coefficient of this variable is 1,890 .

Table 10. Correlation matrix

\begin{tabular}{|c|c|c|c|c|c|c|c|}
\hline & $\operatorname{costfac} 2$ & costfac 3 & knowfac3 & knowfac4 & highaccum pat & size200 & bipublifun_old \\
\hline $\operatorname{costfac} 2$ & 1,0000 & & & & & & \\
\hline costfac3 & 0,5848 & 1,0000 & & & & & \\
\hline knowfac3 & 0,2783 & 0,2885 & 1,0000 & & & & \\
\hline knowfac4 & 0,3893 & 0,3388 & 0,4532 & 1,0000 & & & \\
\hline highaccum & 0,1273 & 0,0730 & 0,0449 & 0,0823 & 1,0000 & & \\
\hline pat & 0,0719 & 0,0301 & 0,0378 & 0,0591 & 0,0794 & & \\
\hline size200 & $-0,1712$ & $-0,1425$ & $-0,1187$ & $-0,0970$ & $-0,1004$ & 1,0000 & \\
\hline bipublifun_old & 0,2472 & 0,1581 & 0,1037 & 0,1737 & 0,2450 & $-0,1083$ & 1,0000 \\
\hline
\end{tabular}

\section{Source: Own elaboration through the PITEC database}

Finally, the Table 10 represents the correlation matrix between the independent variables. From this it is concluded that there is no high correlation between the variables, as most of them are under 0,3 , for which we have not encountered any possible problem of multicollinearity. From the analysis of the results, it seems to be evident that certain obstacles are related to each other. There is a higher degree of correlation between the financial obstacles lack of external financing to the company and cost of innovation too high. In the Table 10, values with a correlation of more than 0,3 are marked in yellow and values of more than 0,4 are marked in red.

\section{Conclusions}

The objective of this paper is to highlight the role of public financing for companies and their investments in R\&D, and secondly, to find the size of obstacles that the firms face when innovating with this form of financing. For this, using the PITEC database, two models are developed; the Logit model and the Tobit model.

The variable bipublifun_old, which shows which companies received public funding in the years before 2014, shows that companies are more likely to receive public funding in that year again for the company to invest in innovative activities.

On the other hand, this paper highlights the sectors that receive more public funding (Annex A) and shows that $75 \%$ of public funding is accumulated in 8 sectors. Through the variable highacum, which contains the sectors that have received the majority of the public financing of the years 2008-2014, it is shown that if a company belongs to a sector that receives a high level of public funding, this increases its chances of receiving state funding. Specifically, some of the sectors that receive the most public funding are the sectors of $R \& D$, telecommunications, aeronautics and space construction and pharmacy (Annex B).

However, biotechnology still does not receive the support of the Public Administrations that it supposedly requires in terms of public funding, at least not in the same way as in other European countries, although there are signs of improvement in recent years (Annex C).

It has been verified that if the company has patented or not previously is a relevant fact to receive or not public financing. Perhaps this circumstance has to be put into perspective with the reduction of innovation costs, because apparently, they 
are considered positively by the Public Administration when granting subsidies. The ingenuity with creative, technological, effective and patentable results is supposedly quoted at the time of the granting of public funds.

In our opinion, once the sectors most benefited by public funding have been recognized, it would be of interest to investigate further in other types of companies that have been successful in the granting of subsidies and such analysis could be strengthened and improved by having Annex D in mind, which broadens the perspective of the time examined (from 2008 to 2014). Undoubtedly, one of the factors that can be affected is the size of the companies, hence the perspective of time to see their evolution.

In conclusion, we are aware of the relevance that this type of analysis can have in the present in the face of researchers and the general public, always interested in sharing public resources well.

\section{References}

Almus, M., \& Czarnitzki, D. (2003). The effects of public R\&D subsidies on firms' innovation activities: The case of Eastern Germany. Journal of Business \& Economic Statistics, 21(2), 226-236. https://doi.org/10.1198/073500103288618918

Antonelli, C., \& Crespi, F. (2013). The "Matthew" effect in R\&D public subsidies: The Italian evidence. Technological Forecasting and Social Change, 8(80), 1523-1534. https://doi.org/10.1016/j.techfore.2013.03.008

Aschhoff, B. (2008). Who gets the money? The dynamics of R\&D project subsidies in Germany. ZEW - Centre for European Economic Research Discussion Paper, 8-18. https://doi.org/10.2139/ssrn.1113722

Asociación Española de Bioempresas. (2016). Informe ASEBIO 2015: Situación y tendencias del sector de la biotecnología en España. 1a edición, Cyan proyectos editoriales SA, España.

Bank of Spain (2006). Informe Anual 2005. Banco de España, Madrid,Spain.

Bator, F. (1958). The anatomy of market failure. Quarterly Journal of Economics, 782, 351-379. https://doi.org/10.2307/1882231

Becker, B. (2015). Public R\&D policies and private R\&D investment: a survey of the empirical evidence». Journal of Economic Surveys, 29(5), 917-942. https://doi.org/10.1111/joes.12074

Becker, L. (2015). Effectiveness of public innovation support in Europe: Does public support foster turnover, employment and labour productivity? Discussion Papers, Center for European Governance and Economic Development Research, 236.

Bérubé, C., \& Mohnen, P. (2009). Are firms that receive R\&D subsidies more innovative? Canadian Journal of Economics/Revue canadienne d'économique, 42(1), 206-225. https://doi.org/10.1111/j.1540-5982.2008.01505.x

Blanes, J. V., \& Busom, I. (2004). Who participates in R\&D subsidy programs? The case of Spanish manufacturing firms. Research policy, 10(33), 1459-1476. https://doi.org/10.1016/j.respol.2004.07.006

Bloom, N., Griffith, R., \& Van Reenen, J. (2002). Do R\&D tax credits work? Evidence from a panel of countries 1979-1997. Journal of Public Economics, 85(1), 1-31. https://doi.org/10.1016/S0047-2727(01)00086-X

Busom, I. (1999). An empirical evaluation of the effects of R\&D subsidies. Burch Working Paper, no B99-05. https://doi.org/10.2139/ssrn.170561

Busom, I., \& Vélez, J. A. (2016). Estudios econométricos PITEC 2016: inversión privada en I+D, apoyo público e innovación en los años de crisis. Fundación Española para la Ciencia y la Tecnología, FECYT.

Cappelen, A., Raknerud, A., \& Rybalka, M. (2012). The effects of R\&D tax credits on patenting and innovations. Research Policy, 41(2), 334-345. https://doi.org/10.1016/j.respol.2011.10.001

Carmichael, J. (1981). The effects of mission-oriented public R\&D spending on private industry. Journal of Finance, 36(3), 617-627. https://doi.org/10.1111/j.1540-6261.1981.tb00648.x

Carrizosa, M. T., Blasco, A. S., \& Quevedo J. G. (2016). Estudios econométricos PITEC 2016: Restricciones financieras y el abandono de proyectos de innovación en las empresas españolas». Fundación Española para la Ciencia y la Tecnología, FECYT.

Clausen, T. H. (2007). Do subsidies have positive impacts on R\&D and innovations activities at the firm level? TIK Working papers on Innovation Studies, Centre for technology, innovation and culture, no 20070615, Oslo.

Cobbenhagen, J. (2000). Successful innovation: towards a new theory for the management of SMEs. Edward Elgar Publishing Ltd, Cheltenham, United Kingdom. 
Cohen, W. M., \& Levinthal, D. A. (1989). Innovation and Learning: The two faces of R\&D. Economic Journal, 99(397), 569-596. https://doi.org/10.2307/2233763

Cooke, P., Boekholt, P., \& Tödtling, F. (2000). The Governance of Innovation in Europe: Regional Perspectives on Global Competitiveness. Pinter, London, United Kingdom.

COTEC (2016). Informe COTEC 2016: Innovación en España. Fundación COTEC para la Innovación, Madrid, Spain.

Czarnitzki, D., \& Licht, G. (2006). Additionality of public R\&D grants in a transition economy: the case of Eastern Germany». The Economics of Transition, 14(1), 101-131. https://doi.org/10.1111/j.1468-0351.2006.00236.x

Czarnitzki, D., Hottenrott, H., \& Thorwarth, S. (2011). Industrial research versus development investment: the implications of financial constraints. Cambridge Journal of Economics, 35(3), 527-544. https://doi.org/10.1093/cje/beq038

David, P., \& Hall, B. H., \& Toole, A. (2000). Is public R\&D a complement or substitute for private R\&D? A review of the econometric evidence. Research Policy, 29, 497-529. https://doi.org/10.1016/S0048-7333(99)00087-6

Duguet, E. (2003). Are R\&D subsidies a substitute or a complement to privately funded R\&D? Evidence from France using propensity score methods for non-experimental data. Cahier de la MSE EUREQua Working Paper, no 2003.75. https://doi.org/10.2139/ssrn.421920

Fernández-Gual, V., \& Segarra-Blasco, A. (2013). The Impact of Cooperation on R\&D, Innovation and Productivity: An Analysis of Spanish Manufacturing and Services Firms. XREAP Working Paper, 2013/08. https://doi.org/10.2139/ssrn.2357297

Galia, F., Mancini, S., \& Morandi V. (2012). Obstacles to innovation: what hampers innovation in France and Italy? Paper submitted to the DRUID Society Conference 2012 innovation and competitiveness Dynamics of Organizations, Industries, Systems and Regions, Copenhagen Business School, Denmark.

Galia, F., Mancini, S., \& Morandi V. (2015). Obstacles to innovation and firms innovation profiles: are challenges different for policy makers? 1st International Conference on Business Management, Universitat Politècnica de Valéncia.

García-Quevedo, J. (2004). Do public subsidies complement business R\&D? A meta-analysis of the econometric evidence. Kyklos, 57(1), 87-102. https://doi.org/10.1111/j.0023-5962.2004.00244.x

García-Vega, M., \& López, A. (2010). Determinants of abandoning innovative activities: Evidence from Spanish Firms. Cuadernos de Economía y Dirección de la Empresa, 13(45), 69-91. https://doi.org/10.1016/S1138-5758(10)70024-4

González, X., \& Jaumandreu, J., \& Pazó, C. (2005). Barriers to innovation and subsidy effectiveness. The RAND Journal of Economics, 36(4), 930-949.

González, X., \& Pazó, C. (2008). Do public subsidies stimulate private R\&D spending? Research Policy, 37(3), 371-389.

Guijarro, A. M.; Van Auken, H., \& Perez de Lema, D. G. (2009). Barriers to innovation among Spanish manufacturing SMEs. Journal of Small Business Management, 47, 465-488. https://doi.org/10.1111/j.1540-627X.2009.00279.x

Hadjimanolis, A. (1990). Barriers to innovation for SME in a small less developed country (Cyprus). Technovation, 19, 561-570. https://doi.org/10.1016/S0166-4972(99)00034-6

Hall, B. (2002). The financing of research and development. Oxford Review of Economic and Policy, 18(1), 35-51. https://doi.org/10.1093/oxrep/18.1.35

Hausman, A. (2005). Innovativeness among small businesses: theory and propositions for future research. Industrial Marketing Management, 8(34), 773-782. https://doi.org/10.1016/j.indmarman.2004.12.009

Heijs, J. (2005). Identification of firms supported by technology policies: the case of Spanish low interest credits. Science and Public Policy, 32(3), 219-230. https://doi.org/10.3152/147154305781779515

Hernandez, J. G. V., \& Santillan, A. G. (2011). Management in the innovation project. Journal of Knowledge Management, Economics and Information Technology, 7, 148-171.

Hewitt-Dundas, N. (2006). Resource and capability constraints to innovation in small and large plants. Small Business Economics, 26, 257-277. https://doi.org/10.1007/s11187-005-2140-3

Hewitt-Dundas, N., \& Roper, S. (2010). Output additionality of public support for innovation: Evidence for Irish manufacturing plants. European Planning Studies, 18(1), 107-122. https://doi.org/10.1080/09654310903343559

Huergo, E., \& Trenado, M. (2010). The application for and the awarding of low-interest credits to finance R\&D projects». Review of Industrial Organization, 37(3), 237-259. https://doi.org/10.1007/s11151-010-9263-7 
Huergo, E., Trenado, M., \& Ubierna, A. (2016). The impact of public support on firm propensity to engage in R\&D: Spanish experience. Technological Forecasting and Social Change, 113, 206-219. https://doi.org/10.1016/j.techfore.2015.05.011

Hujer, R., \& Radić, D. (2005). Evaluating the impacts of subsidies on innovation activities in Germany. Scottish Journal of Political Economy, 52(4), 565-586. https://doi.org/10.1111/j.1467-9485.2005.00356.x

Hussinger, K. (2008). R\&D and subsidies at the firm level: An application of parametric and semiparametric two-step selection models. Journal of Applied Econometrics, 23, 729-747. https://doi.org/10.1002/jae.1016

Kleinknecht, A., Oostendorp, R., \& Pradhan, M. (1997). Patterns and economic effects of flexibility in Dutch labour relations. An exploration of the OSA labour supply and demand panels. Report to the Scientific Council for Government Policy (WRR, V99), SDU publishers, The Hague, Netherlands.

Lach, S. (2002). Do R\&D subsidies stimulate or displace private R\&D? Evidence from Israel. The Journal of Industrial Economics, 50(4), 369-390. https://doi.org/10.1111/1467-6451.00182

Leiponen, A. (2005). Skills and Innovation. International Journal of Industrial Organization, 23(5-6), 303-323. https://doi.org/10.1016/j.ijindorg.2005.03.005

Leiponen, A., \& Helfat, C. E. (2010). Innovation objectives, knowledge sources, and the benefits of breadth. Strategic Management Journal, 31, 224-236. https://doi.org/10.1002/smj.807

Levy, D., \& Terleckyj, N. (1983). Effects of government R\&D on private R\&D investment and productivity: A macroeconomic analysis». Bell Journal of Economics, 14(4), 551-561. https://doi.org/10.2307/3003656

Leyden, D. P., \& Link, A. (1991). Why are government and private research and development complement? ». Applied Economics, 23, 1673-1681. https://doi.org/10.1080/00036849100000132

Lucena, A., \& Afcha, S. (2014). Public support for R\&D, knowledge sourcing and firm innovation: Examining a mediated model with evidence from the manufacturing industries». CENTRUM Católica's Working Paper Series, no 2014-06-0002.

Mankiw, G., Kneebone, R., McKenzie, K., \& Row, N. (2002). Principles of microeconomics. 2nd edition, Thomson-Nelson, United States.

Martin, S., \& Scot, J. T. (2000). The nature of innovation market failure and the design of public support for private innovation». Research Policy, 29, 437-447. https://doi.org/10.1016/S0048-7333(99)00084-0

Medema, S. (2004). Public choice and deviance: a comment». American Journal of Economics and Sociology, 63, 51-54. https://doi.org/10.1111/j.1536-7150.2004.00273.x

Minniti, M., Bygrave, W., \& Autio, E. (2006). Global entrepreneurship monitor report: 2005 executive report. London Business School and Babson College, London, United Kingdom.

Mohnen, P., Mairesse, J., \& Dagenais, M. (2004). Innovativeness: a comparison across seven European countries. Economics of Innovation and New Technology, 13, 23-35.

OECD (2005). Manual de Oslo: Guía para la recogida e interpretación de datos sobre innovación. 3rd edition, OECD publications, Paris, France.

OECD (2016). Government $R \& D$ funding and company behaviour: measuring behavioural additionality. OECD publications, Paris, France.

Puffal, D. P., Spricigo, G., Ruffoni, J., \& Teixeira, R. (2016). The public funds influence for innovation: an analysis of brazilian university-industry interaction». International Association for Management of Technology, 242.

Ribas, A. F. (2009). Public support to private innovation in multi-level governance systems: An empirical investigation». Science and Public Policy, 36, 457-467. https://doi.org/10.3152/030234209X460953

Rogers, E. M. (2003). Diffusion of Innovations. 5th Edition, Free Press, New York.

Sanz-Menéndez, L., \& Cruz-Castro, L. (2005). Explaining the science and technology policies of regional governments. Unidad de Políticas Comparadas, 05-10.

Schibany, A., Streicher, G., Gretzmacher, N., Falk, M., Falk, R., Knoll, N., .. Wörter, M. (2004). Evaluation FFF-Impact Analysis. Institute of technology and regional policy interreg, Research report series, 22.

Takalo, T., Tanayama, T., \& Toivanen, O. (2013). Estimating the benefits of targeted R\&D subsidies». Review of economics and statistics, 95(1), 255-272. https://doi.org/10.1162/REST_a_00280

Tiwari, R., \& Buse, S. (2007). Barriers to innovation in SMEs: Can the internationalization of R\&D mitigate their effects? 
Working Papers, Technologie- und Innovationsmanagement, Technische Universität Hamburg-Harburg, no 50.

Vargas-Hernandez, J. G., \& Garcia-Santillan, A. (2011). Management in the innovation project. Journal of Knowledge Management, Economics and Information Technology, 7, 148-171.

Varghese, P. G. (2013). A communication-focused model for learning and education. Business Education \& Accreditation, 5, 1171-130.

Verworn, B., Herstatt, C., \& Nagahıra, A. (2006). The impact of the fuzzy front end on new product development success in Japanese NPD projects. Working Papers, Technologie- und Innovationsmanagement, Technische Universität Hamburg-Harburg, 39.

Wallsten, S. J. (2000). The effects of government-industry R\&D programs on private R\&D: the case of the small business innovation research program. RAND Journal of Economics, 31(1), 82-100. https://doi.org/10.2307/2601030

Wong, P. K., \& He, Z. L. (2003). The moderating effect of a firm's internal climate for innovation on the impact of public R\&D support programmes. International Journal of Entrepreneurship and Innovation Management, 3, 525-545. https://doi.org/10.1504/IJEIM.2003.003941

Zimmermann, V. (2016). SMEs face a wide range of barriers to innovation-support policy needs to be broad-based». $K f W$ Research Focus on Economics, 130.

Zúñiga-Vicente, J. A., Alonso-Borrego, C., Forcadell, F. J., \& Galán, J. I. (2014). Assessing the effect of public subsidies on firm R\&D investment: a survey. Journal of Economic Surveys, 28(1), 36-67.

https://doi.org/10.1111/j.1467-6419.2012.00738.x 


\section{Annexes}

Annex A. Description of the sectors according to the accumulation of public financing

\begin{tabular}{|c|c|c|c|c|}
\hline Sector code & Sector & Public finance percentage & Sum & $\begin{array}{l}\text { Accumulation of public } \\
\text { financing }\end{array}$ \\
\hline 37 & R\&D services & $25,78 \%$ & 25,78 & High \\
\hline 32 & Telecommunications & $12,29 \%$ & $38,07 \%$ & High \\
\hline 21 & Aeronautical and space construction & $8,53 \%$ & $46,60 \%$ & High \\
\hline 38 & Other activities & $7,80 \%$ & $54,41 \%$ & High \\
\hline 33 & $\begin{array}{l}\text { Programming, consulting and other } \\
\text { computer activities }\end{array}$ & $6,59 \%$ & $61,00 \%$ & High \\
\hline 19 & Motor vehicles & $6,45 \%$ & $67,44 \%$ & High \\
\hline 11 & Pharmacy & $4,96 \%$ & $72,41 \%$ & High \\
\hline 16 & Computer, electronic and optical products & $2,79 \%$ & $75,20 \%$ & High \\
\hline 17 & Electrical equipment and supplies & $2,65 \%$ & $77,85 \%$ & Medium \\
\hline 18 & Other machinery and equipment & $1,98 \%$ & $79,83 \%$ & Medium \\
\hline 28 & Construction & $1,83 \%$ & $81,66 \%$ & Medium \\
\hline 10 & Chemistry & $1,74 \%$ & $83,40 \%$ & Medium \\
\hline 3 & Food, beverages and tobacco & $1,58 \%$ & $84,98 \%$ & Medium \\
\hline 26 & Energy and water & $1,54 \%$ & $86,52 \%$ & Medium \\
\hline 22 & Other transport equipment & $1,38 \%$ & $87,90 \%$ & Medium \\
\hline 15 & Metallic manufactures & $1,32 \%$ & $89,22 \%$ & Medium \\
\hline 20 & Shipbuilding & $1,05 \%$ & $90,27 \%$ & Medium \\
\hline 30 & Transportation and storage & $1,02 \%$ & $91,30 \%$ & Low \\
\hline 14 & Metallurgy & $0,99 \%$ & $92,29 \%$ & Low \\
\hline 12 & Rubber and plastics & $0,95 \%$ & $93,23 \%$ & Low \\
\hline 2 & Oil industries & $0,90 \%$ & $94,13 \%$ & Low \\
\hline 13 & Non-metallic mineral products & $0,82 \%$ & $94,95 \%$ & Low \\
\hline 41 & Health activities and social services & $0,77 \%$ & $95,72 \%$ & Low \\
\hline 34 & $\begin{array}{c}\text { Other information and communication } \\
\text { services }\end{array}$ & $0,69 \%$ & $96,41 \%$ & Low \\
\hline 29 & Commerce & $0,65 \%$ & $97,06 \%$ & Low \\
\hline 35 & Financial and insurance activities & $0,63 \%$ & $97,69 \%$ & Low \\
\hline 0 & Agriculture, forestry and fishing & $0,39 \%$ & $98,09 \%$ & Low \\
\hline 24 & Other manufacturing activities & $0,34 \%$ & $98,43 \%$ & Low \\
\hline 43 & Other services & $0,25 \%$ & $98,67 \%$ & Low \\
\hline 4 & Textile & $0,23 \%$ & $98,91 \%$ & Low \\
\hline 27 & $\begin{array}{l}\text { Sanitation, waste management and } \\
\text { decontamination }\end{array}$ & $0,18 \%$ & $99,09 \%$ & Low \\
\hline 39 & $\begin{array}{c}\text { Administrative activities and auxiliary } \\
\text { services }\end{array}$ & $0,14 \%$ & $99,23 \%$ & Low \\
\hline 23 & Furniture & $0,12 \%$ & $99,35 \%$ & Low \\
\hline 8 & Paper and cardboard & $0,11 \%$ & $99,46 \%$ & Low \\
\hline 40 & Education & $0,10 \%$ & $99,55 \%$ & Low \\
\hline 5 & Confectionery & $0,09 \%$ & $99,64 \%$ & Low \\
\hline 1 & Extractive industries & $0,07 \%$ & $99,71 \%$ & Low \\
\hline 25 & $\begin{array}{c}\text { Repair and installation of machinery and } \\
\text { equipment }\end{array}$ & $0,07 \%$ & $99,78 \%$ & Low \\
\hline 7 & Wood and cork & $0,05 \%$ & $99,84 \%$ & Low \\
\hline 36 & Real estate activities & $0,05 \%$ & $99,89 \%$ & Low \\
\hline 9 & Graphic arts and reproduction & $0,05 \%$ & $99,94 \%$ & Low \\
\hline 6 & Leather and footwear & $0,05 \%$ & $99,98 \%$ & Low \\
\hline 31 & Hostelry & $0,01 \%$ & $99,99 \%$ & Low \\
\hline 42 & $\begin{array}{c}\text { Artistic, recreational and entertainment } \\
\text { activities }\end{array}$ & $0,01 \%$ & $100,00 \%$ & Low \\
\hline
\end{tabular}

Source: Own elaboration through the PITEC database 
Annex B. Histogram of the variable bipublifun_old with respect to the dependent variable bipublifun

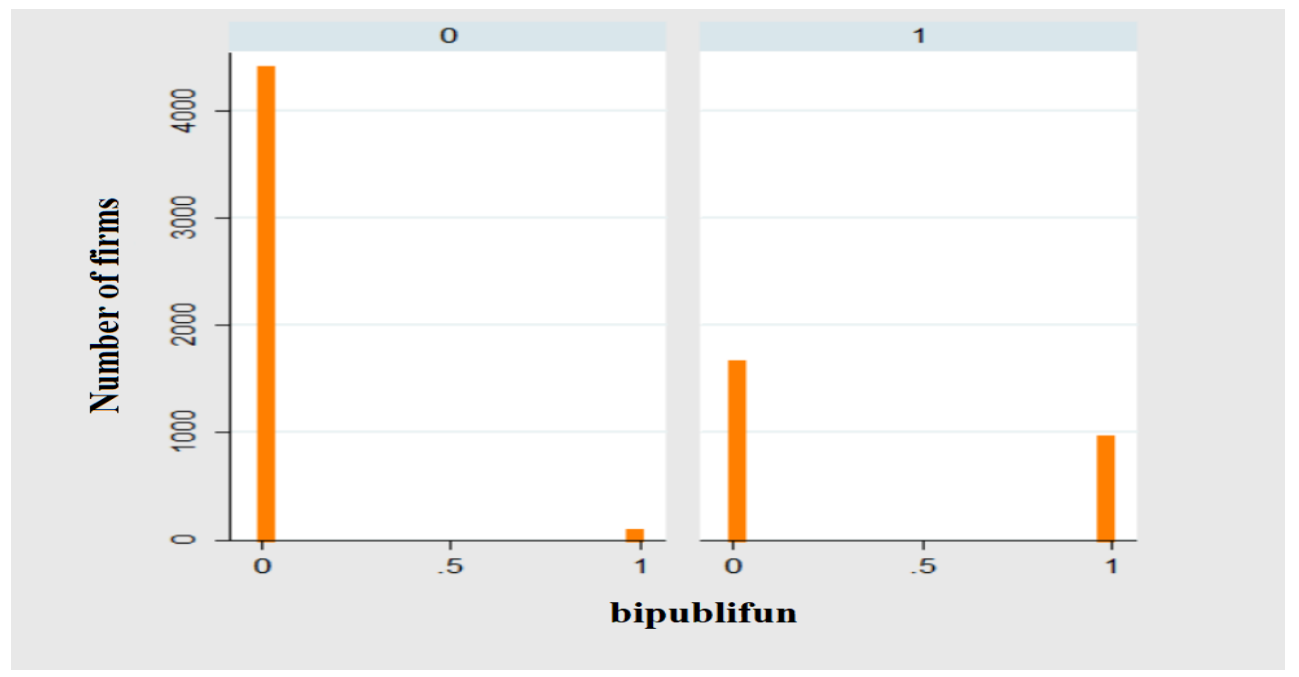

Source: Own elaboration through the PITEC database

Annex C. Growth of biotechnology in Spain

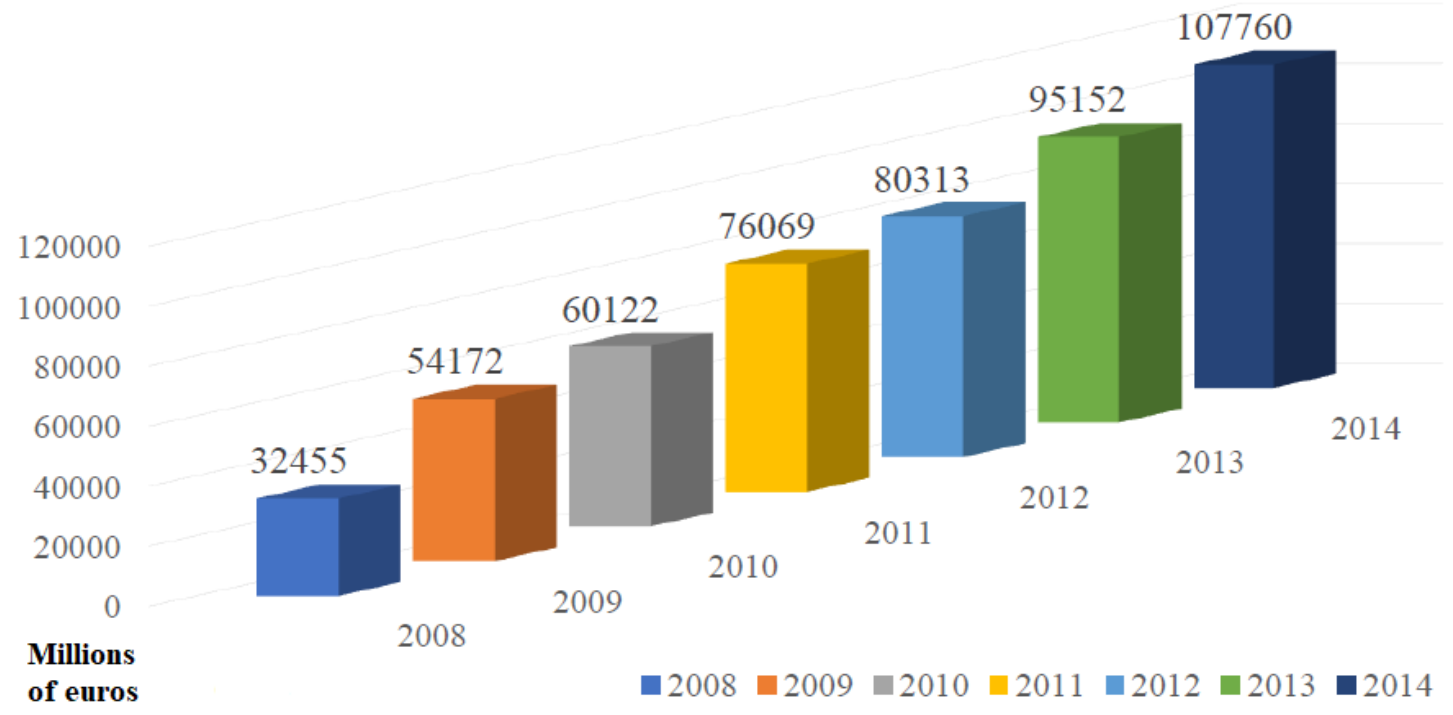

Source: Informe ASEBIO 2015: Situación y tendencias del sector de la biotecnología en España, 2016.

Annex D. bipublifun_old accumulated and with an extension of the time perspective count if ident $>1 \&$ bipublifun $==1$

gsort +ident

local $\mathrm{j}=\_\mathrm{N}$

while ${ }^{\prime} \mathrm{j}^{\prime}<=\_\mathrm{N}\{$

summarize

gen bipublifun_old=1 if bipublifun==1\& bipublifun!= .

replace bipublifun_old $=0$ if bipublifun !=1

local $\mathrm{j}={ }^{\prime} \mathrm{j}+1$

\} 


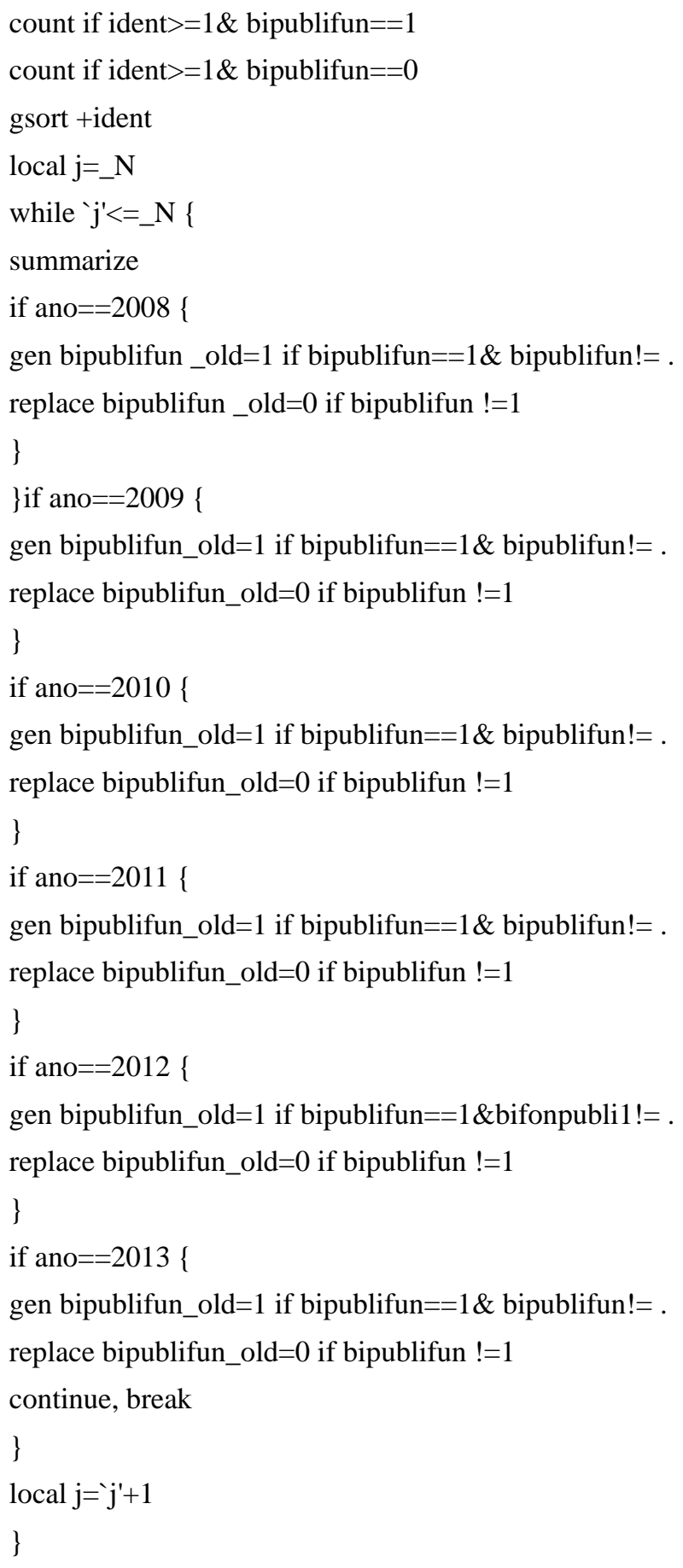

Source: Own elaboration through the PITEC database.

\section{Copyrights}

Copyright for this article is retained by the author(s), with first publication rights granted to the journal.

This is an open-access article distributed under the terms and conditions of the Creative Commons Attribution license which permits unrestricted use, distribution, and reproduction in any medium, provided the original work is properly cited. 